DE

M E D I C I N A

T R O P I C A L

$\mathrm{DE}$

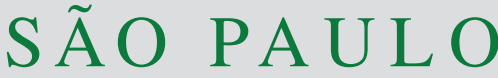

JOURNAL OF THE SÃO PAULO INSTITUTE OF TROPICAL MEDICINE

1Universidade de Brasília, Laboratório de Parasitologia Médica e Biologia de Vetores, Brasília, Distrito Federal, Brazil

2Universidade Federal do Paraná, Laboratório de Parasitologia Molecular, Curitiba, Paraná, Brazil

${ }^{3}$ Universidade de Brasília, Departamento de Estatística, Distrito Federal, Brazil

${ }^{4}$ Universidade Federal de Minas Gerais, Laboratório de Fisiologia de Insetos Hematófagos, Belo Horizonte, MG, Brazil

Correspondence to: Douglas de Almeida Rocha

Universidade de Brasília, Laboratório de Parasitologia Médica e Biologia de Vetores, Campus Universitário Darcy Ribeiro, CEP 70910-900, Brasília, DF, Brazil

Tel: $+556198590-0569$

Fax: +556131070081

E-mail: dougalmeidarocha@gmail.com

Received: 23 January 2020

Accepted: 11 May 2020

\section{Susceptibility of phlebotomine sandflies (Diptera: Psychodidae) collected in the field, to alpha-cypermethrin in four municipalities endemic to leishmaniasis}

\author{
Douglas de Almeida Rocha ${ }^{(1}$, Andrey José de Andrade ${ }^{(12}$, Luciana \\ Reinaldo Moura ${ }^{3}$, Nelder Gontijo Figueiredo ${ }^{(1)}$, Grasielle Caldas D’Ávila \\ Pessoa ${ }^{(1)}$, Marcos Takashi Obara ${ }^{(1)}$
}

\section{ABSTRACT}

Although the chemical control against leishmaniasis began in 1953 in Brazil, little information is available on how this strategy has affected populations of phlebotomine sandflies in the field. The objective of this study was to analyze the susceptibility profile of four populations of phlebotomine sandflies to the insecticide alpha-cypermethrin. Sandflies collected in field in four Brazilian municipalities were evaluated using CDC bottles in different concentrations of alpha-cypermethrin. A total of 1,186 phlebotomine sandflies were used in the bioassays. The $\mathrm{LD}_{50}$ ranged from 1.48 to $2.57 \mathrm{ug} / \mathrm{mL}$ in the field populations. For a dose of $5 \mathrm{ug} / \mathrm{mL}$ of alpha-cypermethrin, the $\mathrm{LT}_{50}$ and $\mathrm{LT}_{95}$ ranged from 17.9 to 27.5 minutes, and $\mathrm{LT}_{95}$ from 39.7 to 61.5 minutes, respectively. All the populations studied were highly susceptible to the insecticide alpha-cypermethrin. Routine studies are needed to detect changes in sandflies susceptibility to insecticides.

KEYWORDS: Phlebotominae. Leishmaniasis. Insecticide resistance. Bioassay. Alphacypermethrin.

Visceral leishmaniasis (VL) and American Cutaneous Leishmaniasis (ACL) are considered zoonoses, and are present in 98 countries throughout the Americas, Europe, Africa and Asia; VL is endemic in 75 countries, and ACL in $87^{1}$. Despite the vector control activities undertaken by the Ministry of Health since 1953, in recent years the leishmaniases have expanded across Brazil to a worrying extent. Between 2007 and 2017, 41,173 confirmed cases of VL and 232,989 cases of ACL were reported in Brazil ${ }^{2}$. This fact leads to a deeper reflection about the true effectiveness of the insecticide used on Brazilian phlebotomine sandfly populations. It should be noted that the insecticide resistance in sandflies has been reported in some old-world countries, related to mutations in sodium channel proteins and/or enzymatic alterations which have still not yet been widely investigated or understood $^{3}$. This information is even more important in areas in which different overlapping programs are used to control endemic diseases, acting simultaneously but in a disjointed manner. In practice, this situation translates the exposing of the sandflies to much higher doses of insecticides than those recommended for controlling this vector, with the potential of selecting resistant individuals ${ }^{4,5}$.

The Ministry of Health of Brazil, since $2003^{6}$, recommends the spraying of home units with $40 \mathrm{mg} / \mathrm{m}^{2}$ of alpha-cypermethrin (BASF, Brazil) for the control of sandflies in areas with ACL and VL transmission, in two different spray cycles with intervals of 120 days, the first cycle after the rainy season ${ }^{7}$. However, no assessment of the 
impact of this insecticide on the susceptibility of Brazilian sandfly populations from endemic areas has been carried out.

In this context, the objective of this study was to describe the susceptibility/resistance profile of Brazilian sandfly populations to the pyrethroid insecticide alpha-cypermethrin.

The sandflies were captured in Minas Gerais State, in the localities of Salgado Filho/Belo Horizonte (S 19 $56^{\prime}$ 56.1'; W $043^{\circ} 58^{\prime} 38.0^{\prime \prime}$ ), Coqueiro/Januaria (S 15 25' 55.6'; W 044 24' 39.7"), and Morrinhos/Montes Claros (S 16 44' 04.7'; W 043 51' 42.3'), and in the Goias State, in the locality Jardim Babilonia/Pirenopolis (S $15^{\circ} 51^{\prime}$ 50.8'; W $048^{\circ}$ 58' 14.2") between April and October 2015. The leishmaniases are endemic in these areas, with a significant number of human and canine cases of VL and ACL. In addition, in these areas, the State Leishmaniasis Control Programs carry out continuous and systematic applications of alpha-cypermethrin for controlling the high density of sandflies. Light traps were installed, in the intra and peridomicile, in the municipalities on three consecutive nights (6:00 pm-7:00 am). The captured sandflies were maintained for two hours in the dark with a $30 \%$ sucrose solution for acclimatization prior to the conduction the bioassays.

The bioassays were performed with controlled temperature and humidity $\left(26^{\circ} \mathrm{C}\right.$ and $\left.48 \%\right)$ and were carried out by $\mathrm{CDC}$ bottle bioassay methodology ${ }^{8}$. For this, we followed the WHO guideline which recommends adopting the discriminating concentration to determine the concentration that causes $100 \%$ mortality of adults; $250 \mathrm{~mL}$ glass bottles (Wheaton Glass Media Bottles, USA) were impregnated with $1 \mathrm{~mL}$ of alpha-cypermethrin dissolved in acetone solution (P.A Merck, Brazil), in four concentrations (3, 5,7 and $9 \mu \mathrm{g} / \mathrm{bottle})$ prepared from the stock solution $24 \mathrm{~h}$ before the test. Sandflies were exposed to the insecticide for up to $60 \mathrm{~min}$, with the mortality rate recorded every $10 \mathrm{~min}$. Doses of 3, 5, 7 and $9 \mu \mathrm{g} / \mathrm{mL}$ were used to measure lethal doses $\left(\mathrm{LT}_{50}\right.$ and $\left.\mathrm{LT}_{95}\right)$, while the dose of $5 \mu \mathrm{g} / \mathrm{mL}$ was used to estimate the lethal times $\left(\mathrm{LT}_{50}\right.$ and $\left.\mathrm{LT}_{95}\right)$ for the four populations analyzed. An average of 20 specimens was tested per bottle without distinction by sex and in equal proportions (1:1). The insects in the control group were only exposed to acetone. A total of 60 sandflies were used as controls. The insects were colected in intra and peridomicilar areas of
Coqueiro, Morrinhos and Jardim Babilonia. In Salgado Filho, the control was carried out with 30 insects. The tests were repeated three times. Insects which demonstrated a change in their ability to fly and/or immobility were considered dead. Next, the sandflies were transferred to containers without insecticide holding 30\% sucrose solution, which was offered ad libitum; they were kept there for $24 \mathrm{~h}$ under controlled temperature and humidity conditions to evaluate their potential recovery from the knockdown effect (Kdr) characteristic of pyrethroid insecticides. Susceptibility was analyzed using the JMP software, version 10 for Windows (SAS Institute I, Cary, NC, USA) 9 .

A total of 1,186 phlebotomine sandflies were used in the bioassays. Lutzomyia longipalpis was the most frequently captured species in all the localities $(88 \%)$, followed by $\mathrm{Lu}$. ischnacantha (6\%), Lu. renei (3\%), Nyssomyia whitmani (1\%), Evandromyia lenti (0.8\%), Micropygomyia villelai (0.6\%), Ev. (Barrettomyia) série Cortelezzii $(0.2 \%)$, Ev. bacula $(0.2 \%)$, and Brumptomyia avellari $(0.2 \%)$.

Although the initial focus of this research was the susceptibility/resistance of Lu. longipalpis to the pyrethroid insecticide alpha-cypermethrin, other species were seen to occur in lower proportions. Notably, among them there were $N y$. whitmani, a vector of Leishmania braziliensis in Brazil. It was not possible to select only $\mathrm{Lu}$. longipalpis to conduct the tests as the taxonomic identification was only performed after the biological bioassays were complete. This identification depends on the preparation and mounting of dead specimens followed by examination of their external and internal structures ${ }^{10}$; in other words, only after exposure to the insecticide could the species be correctly identified.

In Brazil, the Ministry of Health recommends a single strategy for the chemical control of phlebotomine sandflies in the entire country ${ }^{7}$; this allows us to assume that all urban species are subject to the same pressure from insecticides. Bearing this in mind, we suggest dose-response assays for species that occur in the intra and peridomicile to estimate differences between the susceptibility of each species.

Phlebotomine populations from Salgado Filho, Coqueiro, Morrinhos and Jardim Babilonia showed high susceptibility to the pyrethroid insecticide alpha-cypermethrin. The $\mathrm{LD}_{50}$ and $\mathrm{LD}_{95}$ for the field populations are shown in the Table 1.

Table 1 - Estimated lethal dose of different populations of sandflies exposed to alpha-cypermethrin.

\begin{tabular}{lccc}
\hline Population & $\mathrm{n}$ & $\mathrm{LD}_{50} \mathrm{ug} / \mathrm{mL}(95 \% \mathrm{Cl})$ & $\mathrm{LD}_{95} \mathrm{ug} / \mathrm{mL}(95 \% \mathrm{Cl})$ \\
\hline Salgado Filho & 134 & $2.05(0.02-3.35)$ & $7.01(5.95-9.56)$ \\
Coqueiro & 340 & $2.57(2.07-2.84)$ & $4.14(3.75-5.32)$ \\
Morrinhos & 463 & $1.48(0.22-2.13)$ & $3.39(2.69-4.30)$ \\
Jardim Babilonia & 249 & $2.45(1.11-3.16)$ & $5.80(4.61-11.04)$ \\
\hline
\end{tabular}

LD = lethal dose in micrograms per botlle; $95 \% \mathrm{Cl}=95 \%$ confidence interval 
In the field populations, $\mathrm{LT}_{50}$ ranged from $17.9 \mathrm{~min}$ to $27.5 \mathrm{~min}$, and $\mathrm{LT}_{95}$ from $39.7 \mathrm{~min}$ to $61.5 \mathrm{~min}$ (Table 2). In the mortality analysis performed $24 \mathrm{~h}$ after exposure to alpha-cypermethrin, no recovery from the knockdown effect was observed. However, within the bottles the sandflies exposed to the pyrethroid were consistently seen to lose their legs; this phenomenon was not seen in the control group, in which all the insects remained alive until the end of the experiment. The loss of legs is seen as a sublethal effect for sandflies, making it impossible to dislocate and consequently feed and transmit Leishmania ${ }^{11}$.

Table 2 - Estimated lethal time of different populations of sandflies exposed to $5 \mathrm{ug} / \mathrm{mL}$ alpha-cypermethrin.

\begin{tabular}{lcc}
\hline Population & $\mathrm{LT}_{50}(95 \% \mathrm{Cl})$ & $\mathrm{LT}_{95}(95 \% \mathrm{Cl})$ \\
\hline Salgado Filho & $24.2(20.1-29.1)$ & $39.7(33.3-47.3)$ \\
Coqueiro & $27.5(23.8-31.7)$ & $61.5(53.6-70.6)$ \\
Morrinhos & $19.6(17.0-22.6)$ & $47.2(41.4-53.8)$ \\
Jardim Babilonia & $17.9(13.3-24.2)$ & $40.9(30.9-54.2)$ \\
\hline
\end{tabular}

Lethal time (LT) was expressed in minutes; $\mathrm{LT}_{50}=50 \%$ lethal time; $\mathrm{LT}_{95}=95 \%$ lethal time. $95 \% \mathrm{Cl}=95 \%$ Confidence Interval.

In Brazil, only five studies evaluated the susceptibility of sandflies to insecticides. In the first study, Falcão ${ }^{12}$ tested Lu. longipalpis resistance profile from Gruta da Lapinha, in Minas Gerais for organochlorines DDT and Dieldrin. In 1988, Falcão et al. ${ }^{13}$ evaluated this same population for the pyrethroid deltamethrin. In both studies, sandflies were susceptible. Based on this information and the fact that the Lapinha region had no contact with the insecticide, Alexander et al. ${ }^{11}$ considered this population as a reference in a study that compared it with sandflies from Montes Claros, also in Minas Gerais (location impacted by chemical control). In this experiment, the authors reported a reduction in the susceptibility of the sandflies of Montes Claros to the permethrin and deltamethrin pyrethroids. This was the first record of an insecticide tolerance of sandfly species in South America. Pessoa et al. ${ }^{14}$ after testing sandflies from Gruta da Lapinha indicated this population as a susceptible reference lineage, as it complies with the requirements of The Pan American Health Organization ${ }^{14}$. More recently, González et al..$^{15}$ tested populations of Lu. longipalpis caught in the region of Aracatuba. The results demonstrated the susceptibility of these populations to lambda-cyhalothrin and deltamethrin pyrethroids.

The data on susceptibility, presented here, demonstrate the importance of monitoring populations of sandflies to insecticides, so that detection and control measures can be taken in a timely manner in face of the emergence of resistance in Brazil.
For the tests, sandflies with high physical vigor and visibly healthy were selected, but the use of the CDC trap may have influenced the mortality. The captured species may have suffered injuries caused by the propellers of the apparatus, and this fact can be considered as a limitation of this study.

Populations of phlebotomine sandflies from the localities of Salgado Filho/Belo Horizonte, Coqueiro/ Januaria, Morrinhos/Montes Claros and Jardim Babilonia/ Pirenopolis are susceptible to alpha-cypermethrin and Lu. longipalpis was the predominant species. Considering the importance of bioassay findings in guiding leishmaniasis vector control strategies, laboratory tests should be routinely performed so that changes in the susceptibility of sandflies to insecticides can be timely detected.

\section{ACKNOWLEDGMENTS}

We wish to thank the Minas Gerais Secretary of Health and the Health Departments of Belo Horizonte, Montes Claros and Januaria, as well as the Goias Secretary of Health and the Pirenopolis Health Department for making the collection of sandflies possible and for providing laboratories to conduct the bioassays. We also would like to thank Dr. Rodrigo Gurgel Gonçalves and Dr. Lileia Gonçalves Diotaiuti for providing the infrastructure to conduct the bottle bioassays and to analyze the insect fauna, as well as Dr. Elisa Vianna from the Brazilian Ministry of Health for her suggestions to the text.

\section{AUTHORS' CONTRIBUTIONS}

Douglas de Almeida Rocha: collection, carrying out the experiments, analyzing the results and writing the study; Andrey José de Andrade: project design, results analysis, text review; Luciana Moura: analysis of results and statistical analysis of the study; Nelder de Figueiredo Gontijo: experimental design and validation of susceptibility bioassays; Grasielle Caldas D’Ávila Pessoa: project design, analysis of results, text review; Marcos Takashi Obara: project design, study writing and text review.

\section{CONFLICT OF INTERESTS}

None to declare.

\section{FINANCIAL SUPPORT}

Coordenação de Aperfeiçoamento de Pessoal de Nível Superior (CAPES), Instituto René Rachou - Fiocruz Minas and Universidade Federal de Minas Gerais. 


\section{REFERENCES}

1. World Health Organization. Global leishmaniasis update, 20062015: a turning point in leishmaniasis surveillance. Geneva: WHO; 2017. [cited 2020 May 11]. Available from: https:// www.who.int/leishmaniasis/resources/who_wer9238/en/

2. Brasil. Ministério da Saúde. SINAN: Sistema de Informação de Agravos de Notificação. [cited 2020 May 11]. Available from: http://sinan.saude.gov.br/sinan/

3. Fotakis AE, Giantsis IA, Demir S, Vontas JG, Chaskopoulou A. Detection of pyrethroid resistance mutations in the major leishmaniasis vector Phlebotomus papatasi. J Med Entomol. 2018;55:1225-30.

4. van den Berg H, Yadav RS, Zaim M. Strengthening public health pesticide management in countries endemic with malaria or other major vector-borne diseases: an evaluation of three strategies. Malar J. 2014;13:368.

5. Hassan MM, Widaa SO, Osman OM, Numiary MSM, Ibrahim MA, Abushama HM. Insecticide resistance in the sand fly, Phlebotomus papatasi from Khartoum State, Sudan. Parasit Vectors. 2012;5:46.

6. Camargo-Neves VL, Rodas LA, Cabral G, Pauliquevis Jr C. Avaliação da eficácia Lambdacialotrina para o controle de Lutzomyia longipalpis. Bol Epidemiol Paul. 2007;4:4-11.

7. Brasil. Ministério da Saúde. Secretaria de Vigilância em Saúde. Departamento de Vigilância das Doenças Transmissíveis. Manual de vigilância da leishmaniose tegumentar. Brasília: Ministério da Saúde; 2017.

8. World Health Organization. Test procedures for insecticide resistance monitoring in malaria vector mosquitoes. $2^{\text {nd }} \mathrm{ed}$ Geneva: WHO; 2016. [cited 2020 May 11]. Available from: https://apps.who.int/iris/handle/10665/250677
9. SAS Institute. JMP statistical software. [cited 2020 May 11]. Available from: https://www.jmp.com/

10. Vilela ML, Rangel EF, Lainson, R. Métodos de coleta e preservação de flebotomíneos. In: Rangel EF, Lainson R, organizadores. Flebotomíneos do Brasil. Rio de Janeiro: Fiocruz; 2003. p. 353-67.

11. Alexander B, Barros VC, Souza SF, Barros SS, Teodoro LP, Soares ZR, et al. Suscetibility to chemical insecticides of two Brazilian populations of the visceral leishmaniasis vector Lutzomyia longipalpis (Diptera: Psychodidae). Trop Med Int Health. 2009; 14:1272-7.

12. Falcão AR. Susceptibilidade ao DDT e ao Dieldrin, de uma população normal de Phlebotomus longipalpis, de Minas Gerais, Brasil. Rev Bras Malariol Doencas Trop. 1963;15:411-5.

13. Falcão AR, Pinto CT, Gontijo CM. Susceptibility of Lutzomyia longipalpis to deltamethrin. Mem Inst Oswaldo Cruz. 1988;83:395-6.

14. Pessoa GC, Lopes JV, Rocha MF, Pinheiro LC, Rosa AC, Michalsky EM, et al. Baseline susceptibility to alphacypermethrin in Lutzomyia longipalpis (Lutz \& Neiva, 1912) from Lapinha Cave (Brazil). Parasit Vectors. 2015;8:469.

15. González MA, Bell MJ, Bernhardt SA, Brazil RP, Dilger E, Courtenay O, et al. Susceptibility of wild-caught Lutzomyia longipalpis (Diptera: Psychodidae) sand flies to insecticide after an extended period of exposure in western São Paulo, Brazil. Parasit Vectors. 2019;12:110. 